\title{
Thermal and pasting properties of cassava starch-dehydrated orange pulp blends
}

\author{
Magali Leonel ${ }^{1 *}$; Luciana Bronzi de Souza ${ }^{1}$; Martha Maria Mischan² \\ ${ }^{1}$ UNESP/Centro de Raízes e Amidos Tropicais, R. José Barbosa de Barros, 1780 - 18610-307 - Botucatu, SP - \\ Brasil. \\ ${ }^{2}$ UNESP/Inst. de Biociências - Distrito de Rubião Júnior, s/n - 18618-970 - Botucatu, SP - Brasil. \\ *Corresponding author < mleonel@fca.unesp.br>
}

\begin{abstract}
Instant mixtures are easy to prepare and frequently present functional appeals. A quality parameter for instant mixtures is their rheological behavior. This study aimed at evaluating the effects of extrusion parameters on the pasting properties of cassava (Manihot esculenta L.) starch and dehydrated orange (Citrus sinensis (L.) Osbeck) pulp mixtures. The variable parameters were moisture of mixtures $(12.5$ to $19 \%)$, barrel temperature $\left(40\right.$ to $\left.90^{\circ} \mathrm{C}\right)$ and screw rotation (170 to $266 \mathrm{rpm}$ ). The extruded mixtures did not show gelatinization enthalpy. Moisture had the greatest effect on paste properties. The initial pasting viscosity (before heating) of RVA (Rapid visco analyzer) is the most relevant parameter to instant mixtures. The highest cold viscosity values were obtained when mixtures were extruded under high moisture and high screw speed. High moisture $(19.5 \%)$, intermediate temperature $\left(65^{\circ} \mathrm{C}\right)$ and screw speed $(218 \mathrm{rpm})$ led to extruded mixtures production with low component degradation.
\end{abstract}

Key words: Manihot esculenta, fiber, viscosity, extrusion

\section{Propriedades térmicas e de pasta de misturas de fécula de mandioca e polpa cítrica}

\begin{abstract}
RESUMO: Misturas instantâneas apresentam-se como produtos de fácil preparo e muitas vezes com apelos funcionais. Um parâmetro de qualidade nestas misturas é o comportamento reológico. Avaliou-se o efeito de parâmetros de extrusão sobre as propriedades de pasta de misturas de fécula de mandioca (Manihot esculenta L.) e polpa de laranja (Citrus sinensis (L.) Osbeck) desidratada. A umidade das misturas (12.5 a 19\%), a temperatura de extrusão $\left(40\right.$ a $\left.90^{\circ} \mathrm{C}\right)$ e a rotação da rosca $(170$ a $266 \mathrm{rpm})$ foram considerados parâmetros variáveis. As misturas extrusadas não apresentaram entalpia de gelatinização. A umidade foi o fator de maior efeito sobre as propriedades de pasta. A viscosidade inicial (antes do aquecimento) no RVA (Rapid visco analyzer) é um dos parâmetros mais importantes para misturas instantâneas. Nas condições de elevada umidade e rotação da rosca são observadas as maiores viscosidades a frio. Condições de elevada umidade das misturas $(19,5 \%)$, temperatura $\left(65^{\circ} \mathrm{C}\right)$ e rotação intermediárias (218 rpm) levaram a obtenção de misturas extrusadas com baixa degradação dos componentes.

Palavras-chave: Manihot esculenta, fibra, viscosidade, extrusão
\end{abstract}

\section{Introduction}

The current tendency of customers is to use practical foods easy to prepare and that provide, along with nutritional quality, welfare and benefits to the health. Thus, functional foods have been developed by incorporating proteins, fibers, minerals and/or antioxidants. The segmentation of the functional food market has occurred worldwide as follows: fiber-based products $(40 \%)$; products rich in calcium (20\%); oligosaccharide-based products $(20 \%)$; products containing lactic bacteria $(10 \%)$ and others $(10 \%)$. The largest markets for these products are the USA, Europe and Japan (Menrad, 2003).

Conventional fiber sources include foods "in natura", which contain fibers at considerable quantities (fruits, vegetables and grains), and some fibers separated in the grain processing such as bran and soy fiber used in food enrichment. Some alternative fiber sources are already available in the market or have already been studied, including mango (Mangifera indica L.), apple (Malus domestica), lemon (Citrus limon) and orange (Citrus sinensis L.) (Larrauri, 1999;
Lario et al., 2004; Figuerola et al., 2005; Rodríguez et al., 2006). The addition of fiber to extruded snacks has been limited to a few fiber sources such as wheat (Triticum ssp.) and oats (Avena sativa), sugar beet (Beta vulgaris) fiber, soy (Glycine max L.) fiber and cauliflower (Brassica oleracea L.) fiber (Hsieh et al., 1991; Jin et al., 1995; Stojcesk et al., 2008).

Although fresh orange is largely consumed by Brazilians, its main destination is the frozen concentrated juice production. Orange pulp, a residue of the juice purification process, is composed of vesicles that store the juice and membranes that separate these vesicles into segments. It consists $85 \%$ of the total fibers, of which $38 \%$ are soluble and $47 \%$ are insoluble (Souza et al., 2007).

Extrusion has been frequently used by industries in the development of food products. This processing can efficiently create novel products that might not be possible through other processing methods (Cisneros and Kokini, 2002). Depending on the processing conditions and the raw material composition, extrusion causes rupture of the starch grain, completely destroying the granule organized structure, decreasing the medium viscosity, and releasing amylose and 
amylopectin (Camire and Krumhar, 1990). Cooking fibers through extrusion can change their structural and physicochemical characteristics, presenting the redistribution of insoluble to soluble fiber as the main effect (Larrea et al., 2005).

Brazil is the world's second largest producer of cassava (Manihot esculenta Crantz) starch, which has desirable characteristics for the development of extruded products, including: small quantity or absence of lipids; small quantity of proteins; long amylose chains; low gelatinization temperature, medium-sized starch granules; excellent agglutination properties; pleasant flavor; and white coloration (Franco et al., 2001). Based on the importance of using residues to optimize the processes, as well as on the need of understanding the rheological properties of instant mixtures, this study aimed at evaluating the effect of extrusion operational conditions on thermal and paste properties of citrus pulp and cassava starch mixtures.

\section{Material and Methods}

The employed raw materials were industrial cassava starch and dehydrated orange pulp (particle size of $0.25 \mathrm{~mm}$ ). Following the assessment of moisture and total fiber content in raw materials (AACC, 1983), a cassava starch and citrus pulp mixture $\left(17 \mathrm{~kg}\right.$ ) was prepared containing $100 \mathrm{~g} \mathrm{~kg}^{-1}$ of fibers on wet basis. After blending in an electric mixer for 5 min, 20 samples of $800 \mathrm{~g}$ were separated for moisture conditioning.

Extrusion was carried out using a complete line of IMBRA RX (Inbramaq), which has a motor coupled with a speed reducer (extrusion by mechanical friction), besides a single extrusion screw, with $130 \mathrm{~mm}$ of barrel diameter, 440 $\mathrm{mm}$ of extruder length, a hydraulic cooling system for temperature control, variable speed, and $45 \mathrm{~kg} \mathrm{~h}^{-1}$ capacity. The extrusion process parameters were:

Constant parameters: extrusion temperature in the $1^{\text {st }}(20$ to $25^{\circ} \mathrm{C}$ ) and $2^{\text {nd }}$ zones $\left(40\right.$ to $\left.45^{\circ} \mathrm{C}\right)$; screw compression ratio (3:1); screw diameter $(19 \mathrm{~mm})$, die diameter $(4 \mathrm{~mm})$; feed rate $\left(150 \mathrm{~g} \mathrm{~min}^{-1}\right)$; and cutting speed $(90 \mathrm{rpm})$.

Variable parameters: feed moisture; barrel temperature in the $3^{\text {rd }}$ zone; and screw speed (Table 1 ). The variation ranges between the upper and the lower limit of variables were established based on preliminary tests.

During the extrusion process a portion of the next material to be tested was used to purge the extruder. After achieving the steady-state flow, $400 \mathrm{~g}$ of extruded sample was

Table 1 - Levels of variation and variable parameters of the extrusion process.

\begin{tabular}{lcrrrrc}
\hline Independent variables & \multicolumn{5}{c}{ Levels of variation } \\
\hline & $-<$ alpha $>$ & -1 & 0 & +1 & $+<$ alpha \\
\hline Screw speed (rpm) & 170 & 190 & 218 & 246 & 266 \\
Extrusion temperature $\left({ }^{\circ} \mathrm{C}\right)$ & 40 & 50 & 65 & 80 & 90 \\
Moisture content $(\%)$ & 12.5 & 14 & 16 & 18 & 19.5 \\
\hline
\end{tabular}

$<$ alpha $>=1.682$ collected in the extruder. Extruded samples were dried $\left(40^{\circ} \mathrm{C}\right)$ to the desired moisture $(9.5-10.5 \%)$ in oven with air circulation. The samples were powdered by a knives mill with screen of $468 \mathrm{~mm}$.

To evaluate the properties of extruded mixtures, a Rapid Visco Analyser (RVA), series 4, Newport Scientific, was used for starch suspensions ( $3.5 \mathrm{~g}$ sample in $25 \mathrm{~mL} \mathrm{H}_{2} \mathrm{O}$ ) corrected to $140 \mathrm{~g} \mathrm{~kg}^{-1}$ wet basis. Ethanol $(1 \mathrm{~g})$ was added to the sample, as recommended for the Extrusion 2 method. The apparent viscosity was expressed as rapid visco units (RVU), with one RVU equaling 12cP. The following characteristics were evaluated based on the obtained graph: paste temperature, viscosity peak, breakdown (difference between the maximum and minimum post-peak viscosity), final viscosity, and setback (difference between the final viscosity and the minimum post-peak viscosity) (Newport Scientific, 1998). Analyses were done in triplicate.

Thermal properties were analyzed through differential scanning calorimetry (DSC), Pyris 1 (Perkin Elmer, USA) in triplicate. Samples (4 mg, dry basis) were weighed in aluminum crucibles and mixed with distilled water $(12 \mu \mathrm{L})$. The crucibles were sealed, kept at room temperature during $2 \mathrm{~h}$ for equilibrium and heated at a ratio of $5^{\circ} \mathrm{C} \min ^{-1}$, from 25 to $100^{\circ} \mathrm{C}$. An empty crucible was used as reference. The onset (To), peak (Tp), conclusion temperature (Tc) and enthalpy $(\mathrm{DH})$ were assessed by the software Pyris 1.

Response Surface Methodology describes the behavior of a system in which the independent variables $\left(\mathrm{X}_{k}\right)$ and the dependent variable or response $\left(Y_{i}\right)$ are combined. The response is a function of the levels at which those factors were combined and defined. Within the proposed variation ranges, i.e. within the region characterized by these levels, the behavior of each response can be predicted in a general form according to the equation 1 :

$\mathrm{Y}_{1}=\beta_{\mathrm{o}}+\beta_{1} \mathrm{X}_{1}+\beta_{2} \mathrm{X}_{2}+\beta_{3} \mathrm{X}_{3}+\beta_{11} \mathrm{X}_{1}^{2}+\beta_{22} \mathrm{X}_{2}^{2}+\beta_{33} \mathrm{X}_{3}^{2}+$ $\beta_{12} \mathrm{X}_{1} \mathrm{X}_{2}+\beta_{13} \mathrm{X}_{1} \mathrm{X}_{3}+\beta_{23} \mathrm{X}_{2} \mathrm{X}_{3}+\varepsilon$

where: $\mathrm{Y}_{1}=$ Dependent variable or response function; $\mathrm{X}_{1}$, $\mathrm{X}_{2}, \mathrm{X}_{3}=$ Values of the independent variables; $\beta_{\mathrm{o}}=$ Coefficient relative to the line interception with the response axis; $\beta_{1}, \beta_{2}, \beta_{3}=$ Linear coefficients assessed through least square method; $\beta_{11}, \beta_{22}, \beta_{33}=$ Coefficients of quadratic variables; $\beta_{12}$, $\beta_{13}, \beta_{23}=$ Coefficients of interaction between independent variables; $\varepsilon=$ Experimental error.

The model was fitted by the option "step-wise" of SAS program; the obtained model was validated through F-test using as denominator the pure error mean square.

\section{Results and discussion}

The properties of unextruded blend cassava starch paste had initial viscosity at $25^{\circ} \mathrm{C}$ close to zero due to the absence of gelatinized starch. The curve had a narrow peak (characteristic of granules presenting structural homogeneity) followed by a sharp fall, even before reaching $95^{\circ} \mathrm{C}$, which revealed little stability of the hot paste during agitation (Figure 1). After the extrusion process initial viscosity (IV) of the extruded products at $25^{\circ} \mathrm{C}$ varied from 5.6 to $63.5 \mathrm{RVU}$. 
The viscosity peak (VP) values ranged from 5.7 to 63.9 RVU. The breakdown of extruded products ranged from 5.5 to 62.0 RVU. The values found for the treatments for final viscosity of extruded products ranged from 1.5 to 24.8 RVU.

Figure 2 shows the viscoamylography profile of cassava starch-dehydrated orange pulp blend extruded in condition of $19.5 \%$ of moisture, $65^{\circ} \mathrm{C}$ of extrusion temperature and $218 \mathrm{rpm}$. Leonel et al. (2009) observed for extruded cassava starch: 5.3 to 14.7 RVU for initial viscosity, 6.3 to $14.6 \mathrm{RVU}$ for viscosity peak, 2.8 to $12.8 \mathrm{RVU}$ for breakdown, 7.2 to 13.1 RVU for final viscosity and 2.5 to 12.5 RVU for setback. Therefore, the differences observed in pasting properties of extruded mixtures of cassava starch and citrus pulp can be due the fiber content.

The initial pasting viscosity (before heating) of RVA is the most relevant parameter to "instant starch". In the ex-

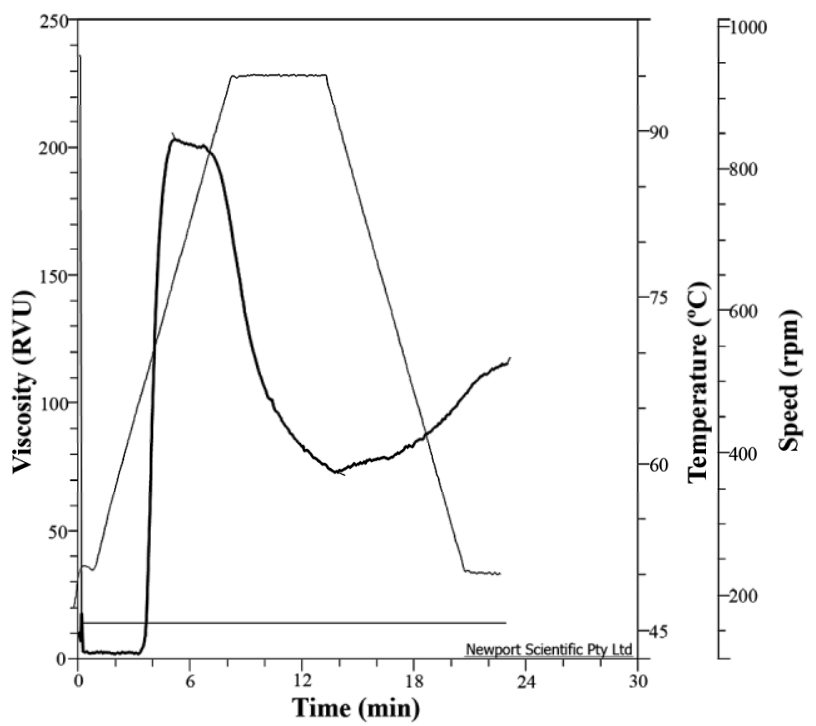

Figure 1 - Viscoamylography profile of unextruded cassava starchdehydrated orange pulp blend.

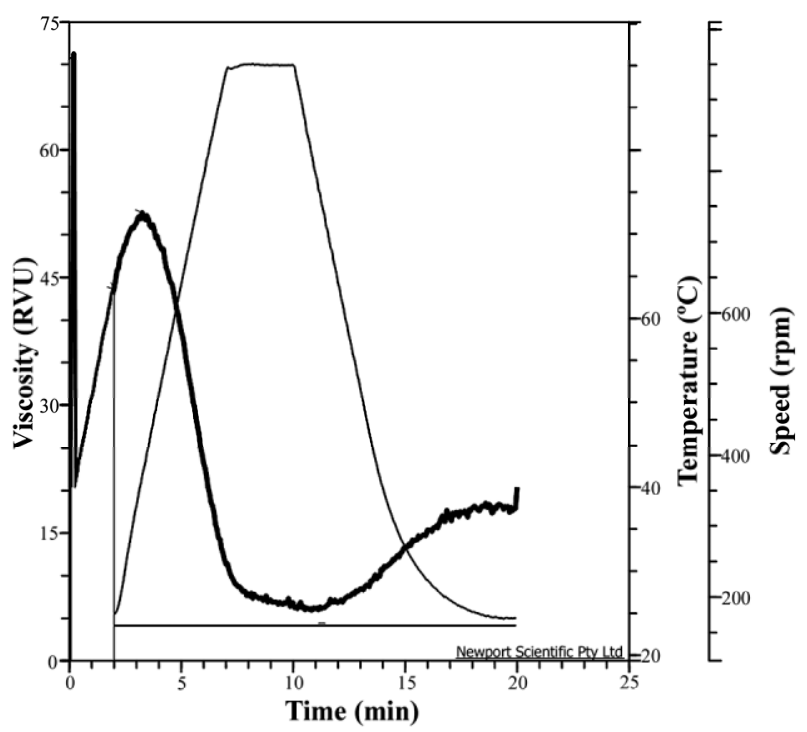

Figure 2 - Viscoamylography profile of extruded cassava starchdehydrated orange pulp blend. truded samples, the starch is already gelatinized, which allows rapid hydration compared to the crude sample. The screw speed and the interaction moisture-screw speed had an effect on initial viscosity (Table 2).

The highest cold viscosity values are obtained when mixtures are extruded under high moisture and high screw speed (Figure 3). The extent of starch gelatinization has been reported primarily as a function of the barrel temperature; however, extrusion conditions and material used possibly increased frictional damage. When fiber is present along with starch, it competes for the limited amount of water available in food system (Santilán-Moreno et al., 2009). The partial solubilization of fiber present in mixtures can affect the initial viscosity. Citrus pulp extrusion leads to partial fiber solubilization, increasing the soluble fraction; this is mainly influenced by temperature and screw rotation (Céspedes et al., 2005).

Table 2 - Regression equation coefficients (model $\mathrm{Y}_{\mathrm{k}}=\mathrm{b}_{0}+$

\begin{tabular}{|c|c|c|c|c|c|}
\hline \multirow[t]{2}{*}{ Parameter } & \multicolumn{5}{|c|}{ Response variables } \\
\hline & IV & VP & $\mathrm{B}$ & RT & FV \\
\hline $\mathrm{b}_{0}$ & 38.30 & 44.47 & 40.33 & 9.06 & 13.20 \\
\hline $\mathrm{b}_{1}$ & 3.73 & 3.62 & 4.44 & $-2.40 * *$ & $-3.22 * *$ \\
\hline $\mathrm{b}_{2}$ & 5.09 & $6.69 *$ & 5.52 & $2.44 * *$ & $3.60 * * *$ \\
\hline $\mathrm{b}_{3}$ & -2.26 & -2.75 & -2.04 & -1.02 & $-1.75^{*}$ \\
\hline $\mathrm{b}_{11}$ & -4.03 & -5.25 & -5.63 & 0.67 & 1.05 \\
\hline $\mathrm{b}_{22}$ & -2.82 & -3.50 & -3.51 & -0.32 & -0.31 \\
\hline $\mathrm{b}_{33}$ & $-5.84 *$ & $-8.09 *$ & $-7.09 *$ & -1.53 & $-2.53^{* *}$ \\
\hline$b_{12}$ & 0.0 & -0.69 & -0.39 & -1.17 & -1.47 \\
\hline $\mathrm{b}_{13}$ & -6.98 & -6.06 & -7.25 & 0.84 & 2.03 \\
\hline $\mathrm{b}_{23}$ & $12.54 * *$ & $11.92 * *$ & $11.17^{*}$ & -0.30 & 0.45 \\
\hline $\mathrm{R}^{2}$ & 0.7351 & 0.7713 & 0.7453 & 0.8206 & 0.8685 \\
\hline
\end{tabular}

$\mathrm{b}_{1}=$ extrusion temperature; $\mathrm{b}_{2}=$ moisture; $\mathrm{b}_{3}=$ screw speed; $\mathrm{IV}=$ viscosity index; $\mathrm{VP}=$ Viscosity Peak; $\mathrm{B} \stackrel{3}{=}$ breakdown; $\mathrm{RT}=$ retrogradation tendency; $\mathrm{FV}=$ final viscosity.

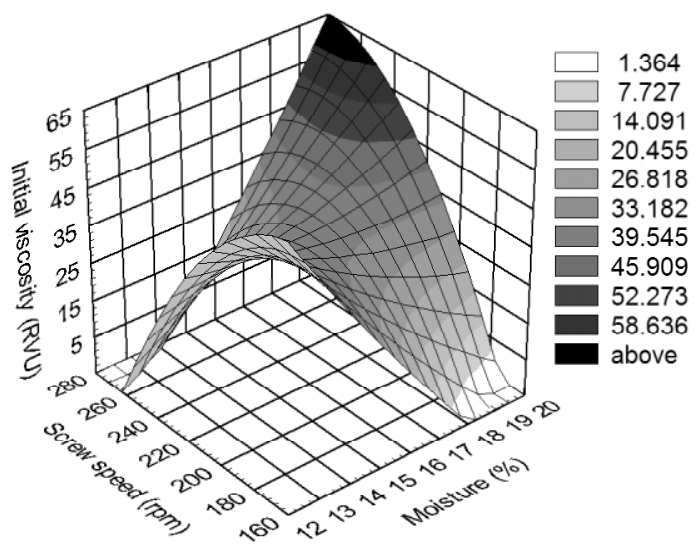

Figure 3 - Effects of moisture and screw speed on the initial viscosity of extruded mixtures at $65^{\circ} \mathrm{C}$. 
Peak viscosity (PV) for extruded products indicates that part of the starch granules maintained their structure, allowing heating and peak formation. Peak values were affected by the initial moisture of samples, the screw rotation and the interaction between these factors. According to the model, the highest peak viscosity occurred under conditions of high moisture (20\%), high speed (245 and $272 \mathrm{rpm}$ ) and extrusion temperature kept at $65^{\circ} \mathrm{C}$ (Figure 4). Low moisture and high screw speed conditions, could have contributed to a higher starch and fiber degradation, reducing the peak viscosity (Figure 4). Hot viscosity is directly related to the starch granule degradation level. If the granule has its structure destroyed, it loses the capacity to swell when heated in water, consequently presenting low hot viscosity. The breakdown of extruded products, which indicates the paste stability at high temperatures under mechanical agitation, was affected by the screw speed and the interaction screw speedmoisture.

Similarly to peak viscosity, the most severe conditions of the extrusion process led to starch structure degradation and fiber solubilization, with no peak and breakdown. The highest breakdown in viscosity occurred under central screw speed conditions (Figure 5).

The setback allows the evaluation of the paste behavior during cooling. When the screw speed is kept in the central condition (218 rpm), the highest setback values (ST) can be

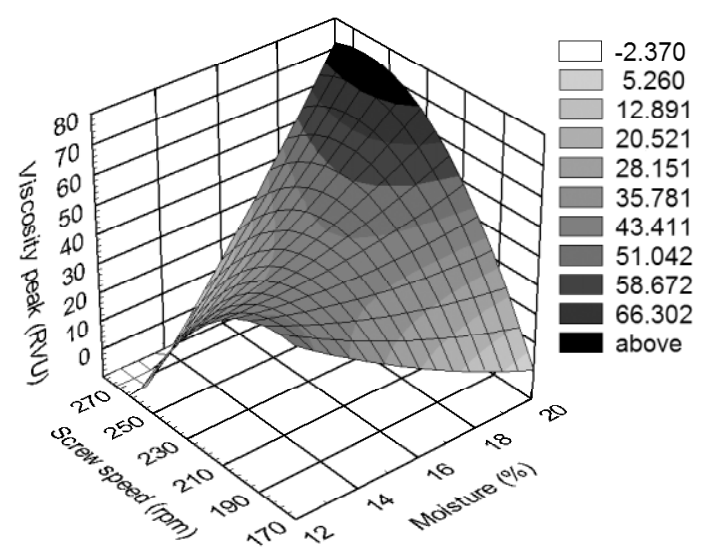

Figure 4 - Effect of moisture content and screw speed on the viscosity peak of extruded mixtures at $65^{\circ} \mathrm{C}$

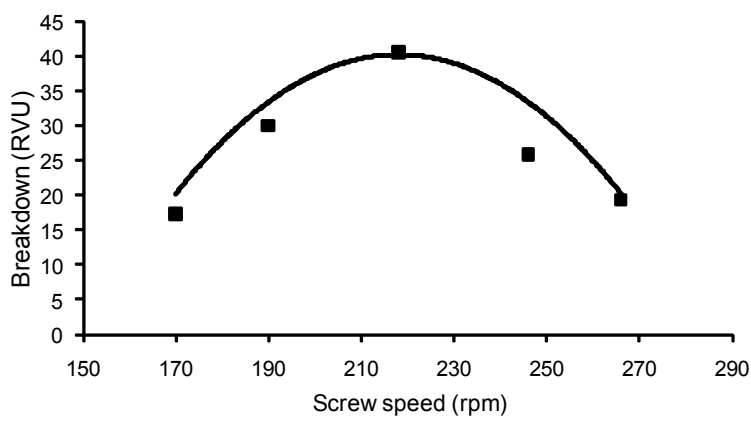

Figure 5 - Effect of screw speed on the breakdown of extruded mixtures. observed under conditions of low temperature and high moisture (Figure 6). After the gelatinization, the polymers that form the starch granule tend to reassociate through hydrogen bond, forming better organized zones. Reassociations among amylose, amylopectin and swollen starch granules lead to tridimensional network constituted of better organized zones (Hoover, 2001). Moisture in extrusion can act as a lubricant agent; at low temperature it may allow lower degradation of the raw material constituents, leading to setback.

The final viscosity (FV) depends on changes in the starch granule structure during the extrusion process. The highest FV values, which indicate less severe treatments allowing the reorganization of molecules, were observed under conditions of low temperature, high moisture and intermediate screw speed (Figures 7, 8 and 9).

Starch gelatinization is a combined process consisting of the hydration of an amorphous region and subsequent melting of crystalline arrays (Randzio and Orlowska, 2005). The gelatinization parameters of mixture of cassava starch and orange pulp before extrusion were: $59.71^{\circ} \mathrm{C}$ of onset $\left(\mathrm{t}_{0}\right)$, $67.53^{\circ} \mathrm{C}$ of peak $\left(\mathrm{t}_{\mathrm{p}}\right), 73.91^{\circ} \mathrm{C}$ of conclusion temperature $\left(\mathrm{t}_{\mathrm{c}}\right)$ and gelatinization enthalpy $(\mathrm{DH})$ of $9.02 \mathrm{~J} \mathrm{~g}^{-1}$. The cassava starch show $64.3^{\circ} \mathrm{C}, 68.3^{\circ} \mathrm{C}$ and $74.4^{\circ} \mathrm{C}$ (onset, peak and con-

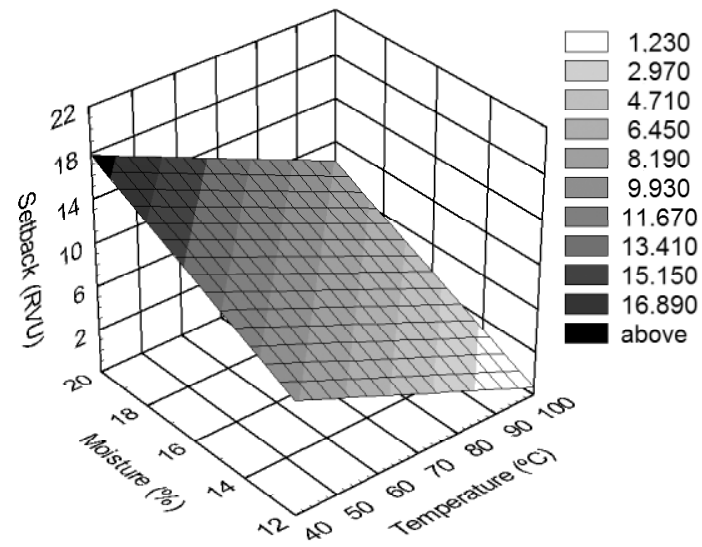

Figure 6 - Effect of moisture content and extrusion temperature on the setback of extruded mixtures under $218 \mathrm{rpm}$.

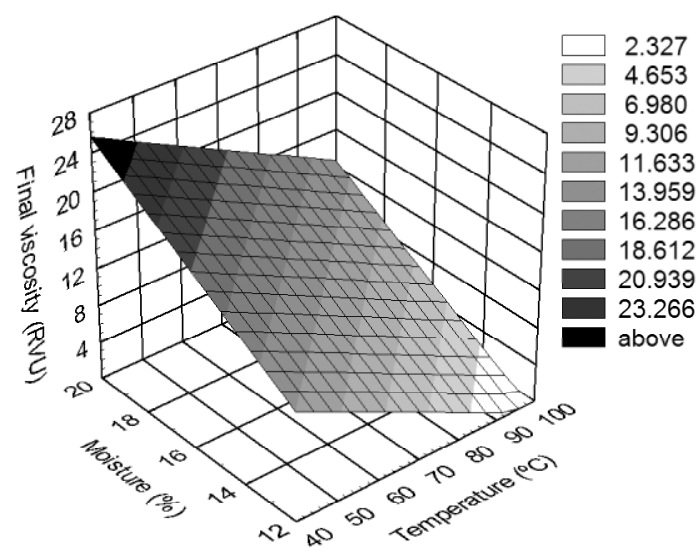

Figure 7 - Effect of moisture content and extrusion temperature on the final viscosity of extruded mixtures under 218 rpm. 


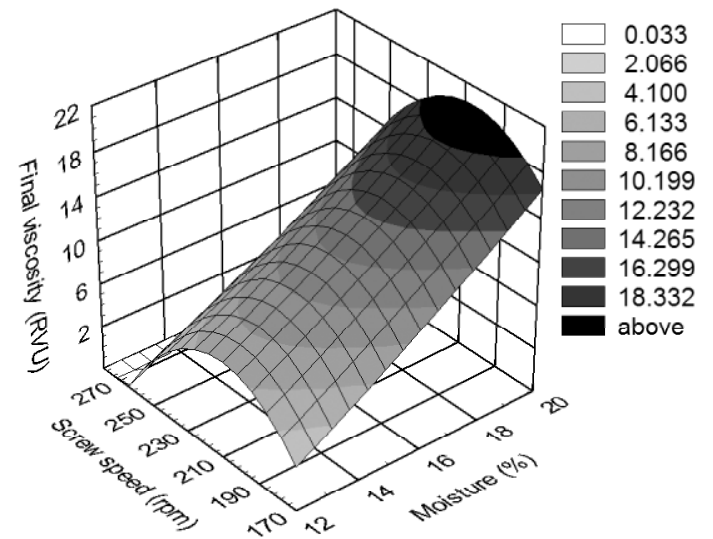

Figure 8 - Effect of moisture content and screw speed on the final viscosity of extruded mixtures at $65^{\circ} \mathrm{C}$.

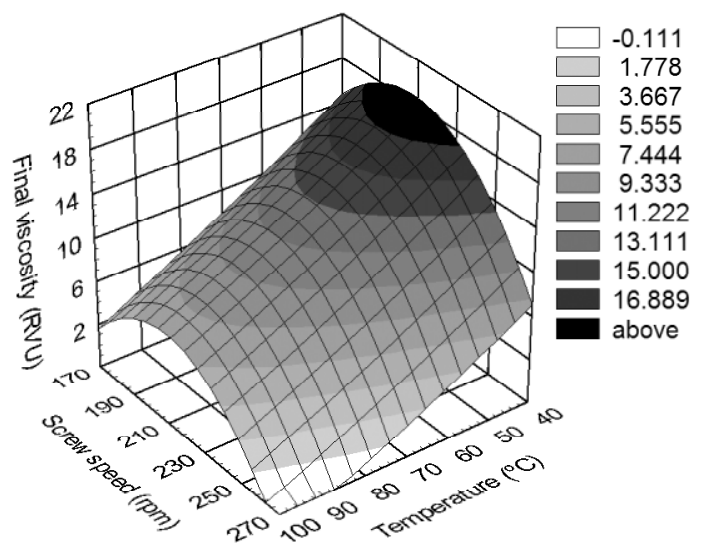

Figure 9 - Effect of extrusion temperature and screw speed o $n$ the final viscosity of extruded mixtures under $16 \%$ moisture.

clusion temperature respectively) with gelatinization enthalpy of $14.7 \mathrm{~J} \mathrm{~g}^{-1}$ (Jane et al., 1999). Differences in the starch gelatinization parameters can be due to less available water in the presence of the orange fiber.

The extruded mixtures do not show gelatinization enthalpy. The absence of residual gelatinization enthalpy in mixtures following extrusion suggests that all starch present in the samples was gelatinized and the differences observed in the paste properties can be due to starch-granule modifications (granule disruption and molecular fragmentation) and other non-starch components (Hagenimanda et al., 2006; Lustosa et al., 2009).

\section{Acknowledgements}

To CNPq for financial support.

\section{References}

American Association of Cereal Chemists [AACC]. 1983. Approved Methods of the American Association of Cereal Chemists. 7ed. AACC, St. Paul, MN, USA.

Camire, M.E; Krumhar, K. 1990. Chemical and nutritional changes in foods during extrusion. Critical Reviews in Food Science and Nutrition 29: 35-57.
Céspedes, M.A.L; Chang, Y.K; Bustos, F.M. 2005. Effect of some operational extrusion parameters on the constituints orange pulp. Food Chemistry 89: 301-308.

Cisneros, F.H.; Kokini, J.L. 2002. A generalized theory linking barrel fill length and air bubble entruoment during extrusion of starch. Journal of Food Engineering 51: 139-149.

Figuerola, F.; Hurtado, M.L.; Estevez, A.M.; Chifelle, I.; Asenjo, F. 2005 Fibre concentrates from apple pomace and citrus peel as potential fibre sources for food enrichment. Food Chemistry 91: 395-401.

Franco, C.M.L.; Daiuto, E.R.; Demiate, I.M.; Carvalho, L.J.C.B.; Leonel, M.; Cereda, M.P.; Vilpoux, O.F.; Sarmento, S.B.S. 2001. General Properties of Starch. Fundação Cargill, São Paulo, SP, Brazil. (in Portuguese).

Hagenimanda, A.; Ding, X.; Fang, T. 2006. Evaluation of rice flour modified by extrusion cooking. Journal of Cereal Science 43: 3846.

Hoover, R. 2001. Composition, molecular structure and physicochemical properties of tuber and root starches: a review. Carbohydrate Polymers 45: 253-267.

Hsieh, F.; Huff, H.E; Lue, S.; Stringer, L. 1991. Twin-screw extrusion of sugar beet fiber and corn meal. Lebensmittel-Wissenschaft und Technologie 24: 495-500.

Jane, J.; Chen, Y.Y.; Lee, L.F.; McPherson, A.E., Wong, K.S.; Radosavljevic, M., Kasemmsuwam, T. 1999. Effects of amylopectin branch chain length and amylose content on the gelatinization and pasting properties of starches. Cereal Chemistry 76: 629-637.

Jin, Z.; Hsieh, F.; Huff, H.E. 1995. Effects of soy fiber, salt, sugar and screw speed on physical properties and microstructure of corn meal extrudate. Journal of Cereal Science 22: 185-194.

Lario, Y.; Sendra, E.; Garcia-Perez, J.; Fuentes, C., Sayas-Barbera, E.; Fernandes-Lopez, J.; Perez-Alvarez, J.A. 2004. Preparation of high dietary fiber powder from lemon juice by-products. Innovative Food Science \& Emerging Technologies 5: 113-117.

Larrauri, J.A. 1999. New approaches in the preparation of high dietary fibre powders from fruit by-products. Trends in Food Science \& Technology 10: 3-8.

Larrea, M.A; Chang, Y.K; Martinez-Bustos, F. 2005. Effect of some operational extrusion parameters on the constituents of orange pulp. Food Chemistry 89: 301-308.

Leonel, M.; Freitas, T.S.; Mischan, M.M. 2009. Physical characteristics of extruded cassava starch. Scientia Agricola 66: 486-493.

Lustosa, B.H.B.; Leonel, M.; Leite, T.D.; Franco, C.M.L.; Mischan, N.M. 2009. Cassava instant flour: effect of extrusion conditions on thermal and viscosity properties. Acta Scientiarum Technology 31: 231-238. (in Portuguese, with abstract in English).

Menrad, K. 2003. Market and marketing of functional food in Europe. Journal of Food Engineering 56: 188-191.

Newport Scientific. 1998. Operation manual series 4: instructions manual. Warriewood, NSW, Australia.

Randzio, S.L.; Orlowska, M. 2005. Simultaneous and in situ analysis of thermal and volumetric properties of starch gelatinization over wide pressure and temperature ranges. Biomacromolecules 6: 3045-3050.

Rodríguez, R.; Jiménez, A.; Fernández-Bolaños, J.; Guillén, R.; Heredia, A. 2006. Dietary fibre from vegetable products as source of functional ingredients. Trends in Food Science \& Technology 17: 3-15.

Santilán-Moreno, A.; Martinéz-Bustos, F.; Castaño-Tostado, E.; AmayaLiano, S. 2009. Physicochemical characterization of extruded blends of corn starch-whey protein concentrade-Agave tequilana fiber. Food and Bioprocess Technology DOI 10.1007/S11947009-0223-x.

Souza, L.B.; Leonel, M.; Mischan, M.M. 2007. Effect of extrusion conditions on the physical properties of snacks of cassava starch and orange pulp. Alimentos e Nutrição 18: 83-91. (in Portuguese).

Stojcesk, V.; Ainsworth, P.; Plunkett, A.; Íbanoglu, S. 2008. The recycling of brewer's processing by-product into ready-to-eat snacks using extrusion processing. Journal of Cereal Science 47: 469-479.

Received January 27, 2010

Accepted October 27, 2010 